Vol. 2, No. 2, 2015

\title{
CAPITALIZATION OF THE INDUSTRIAL ENTERPRISE: SPECIFICS OF MODERN MANAGEMENT
}

A. Y. Mohylova

Doctor of Economics, as. prof.,

Oles Honchar Dnipropetrovsk National University

\begin{abstract}
Based on the cyclical nature of company's capitalization, the paper proves that the productive capital is of high priority in achieving the strategic goal - the growth of company's value. The directions for the growth of company's own capital are determined, and the best of them are identified in terms of organizational constraints in the implementation by the company's owners and economic expediency. The sources of company's own financial resources for the increase of capitalization are analyzed, and the directions for providing company's capitalization in the real sector of the economy are offered.
\end{abstract}

Key words: capitalization, company's value, industrial production, own capital, real sector of economy.

The economic situation in the country is characterized by certain interdependence with the economic activities of economic entities: the increase in the size of companies provides the increase in the degree of their impact on the national economy and increases the resistance to fluctuations in the national economy. The increase in the production of companies is largely the result of using scientific approaches in their management and capitalization. Diverse aspects of valueoriented business management are reflected in the works of foreign scientists [1-8].

The strategy of the industrial company's capitalization should be developed, firstly, through the transformation of the company's productive capital that provides its real capitalization (Fig. 1). After manufacturing goods it is possible to organize the effective influence on the consumer through balanced communication strategies and strategies of positioning the enterprise-producer or its product on the market. This set of actions promotes a strong brand of the company and in this way provides the marketing capitalization. If the company's stock capital is divided into a certain number of shares, then after the company's brand recognition as a result of marketing capitalization, it is expedient to sell the shares to interested market participants - future shareholders, and thus achieve the market capitalization. Increase in the value of capitalization provides a cyclical nature of the process "real capitalization - marketing capitalization - market capitalization".

So, taking into account a cyclical nature of company's capitalization, the author proves that the productive capital is of high priority in achieving the strategic goal - the growth of company's value.

J. Bogutska expresses the opinion on the availability of direct correlation between the increase of company's capital and, as a result, the growth of company's market value $[9, \mathrm{p} .180]$. This statement contradicts to the author's position, according to which the increase of capital can contribute to the growth of company's value only under its effective use (real capitalization), further marketing capitalization and, ultimately, market capitalization. That is, only the effective organization of all the components of company's potential can allow forecasting the growth of its market value.

Strategically important and essential for providing a real capitalization is the management of company's tangible assets. In order to improve the forecasting of future movement of basic assets, O. Molyaka proposes to identify the main factors of impact on the amount of basic assets that are put into effect by using econometric modeling, as well as to find the strength of these factors [10]. The list of impact factors proposed by O. Molyaka consists of the volume of investments, the average number of employees and the total number of enterprises in Ukraine. We believe that to identify the impact of some factors on the productive capital formation in the industrial companies of the real sector of the economy in terms of their capitalization growth, it is necessary to identify purely production factors and find the directions and strength of their impact on the main indicator. In this case the forecasting will be more accurate. These factors include: investments in basic assets, the proportion of production workers in the total number of employees, the cost of finished products. 


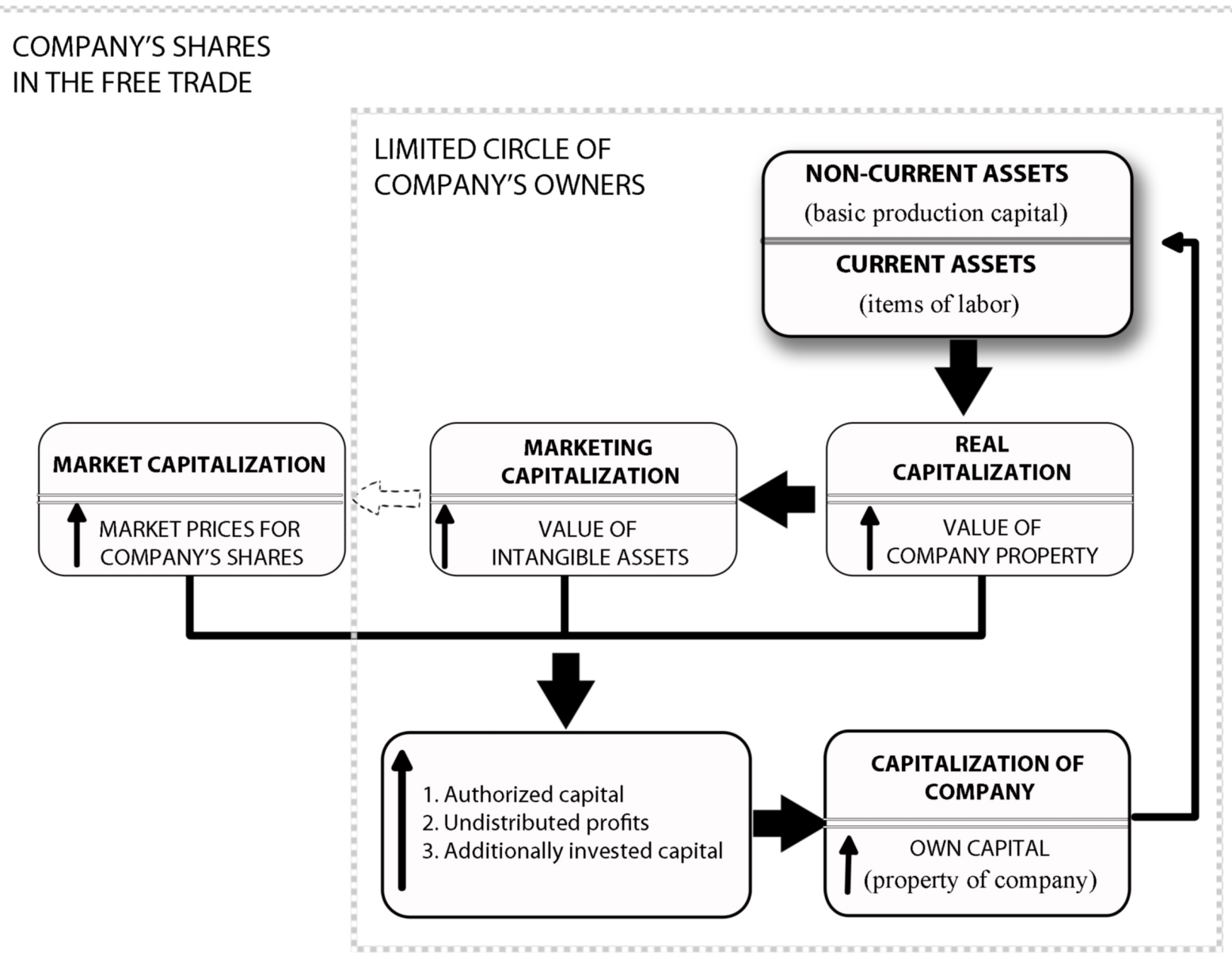

Fig. 1. Process of managing company's capitalization

Finished products of the company are a factor of the future volume of basic assets, but the managerial choice involves making decisions adequate to market requirements only. From this position, under consumer-oriented production the cost of finished products is the result of the market demand formed before. Therefore, it's quite reasonable to take the cost of finished products as one of the factors that determines the necessary amount of company's productive capital - its main basic assets.

The contribution of finished products to the creation of company's productive capital can be estimated by the amount of income from its main activities because it is the income that is the source of enterprise's own financial resources. Thus, we support the conclusion of N. Spasiv concerning the identification of the list of factors influencing the formation of company's basic capital, namely that the income from company's main activities is an objective factor in the formation of basic capital because of the expansion of its investment opportunities [11].
Carrying out economic and mathematical modeling of optimal volumes of basic capital reproduction and determining the list of impact factors, N. Spasiv identifies the volume of products manufactured by the means of labor at the age $t$ [11, p. 163]. However, we believe that the differentiation of basic assets by the age of their operation is expedient only in the production of final products. The account of units of production equipment by the age of their operation proposed by N. Spasiv is very often impossible in actual production processes from the view of practical implementation because the latter involve the production of semi-finished goods or parts (components) of final products using certain units of equipment. Moreover, it is rather inexpedient taking into account a different contribution of technical units to the production cycle and therefore different intensity of work and, consequently, unequal degree of physical depreciation and the need for reproduction caused by it. In other words, concerning large companies of the real sector of the 


\section{Capitalization of the industrial enterprise: specifics of modern management}

economy the age structure of basic assets is not an important factor of company's future capitalization. Therefore, to forecast capitalization of large industrial companies (including those which are vertically integrated) the focus should be made on the value of basic production assets without taking into account their age structure.

N. Spasiv's opinion on the reproduction of basic capital only through the sale of available labor means and purchase of new ones is rather disputable [11, p. 164], because the current realities of the production process and limited financial resources of the company stipulate the reproduction of technical equipment through capital and current repairs. It should be noted that since the repair is episodic it could be made not by the company's repair service but by the third party outsourced.

In addition, one should clarify the phrase of N. Spasiv that "... the use of "outdated" technologies reduces the profitability of main activities" [11, p. 166]. Because this position does not meet the objective requirements of certain technological processes that use "classical" production technology, such as the production of wine and cognac, as well as the chemical or metallurgical production. At the same time, the replacement of outdated equipment with new modern one will really contribute to the reduction of working time due to reduced time for changeover and repair of equipment and, thus, to the growth of labor productivity on this basis.

Furthermore, the features of accounting company's own capital are such that the organization of production on the basis of outdated fixed assets sometimes calls for the additional valuation of noncurrent assets, which at the same time increases company's own capital as a result of the growth of its additional capital, namely of additionally valuated capital, that is one of the directions for the growth of company's own capital. This gives grounds to believe that in such cases the conditions are created to expand the company's own sources for ensuring future capitalization.

Thus, we can distinguish the following directions for the growth of the company's own capital, which ensure its capitalization:

1. Increase in the size of the authorized capital through the contributions to company's authorized capital. However, modern owners of the company are reluctant to resort to such contributions, because they are more likely to invest available financial resources in other areas of business to redistribute the risk. So, the increase of the authorized capital is possible at the expense of contributions from outside investors. However, as a rule, this variant is not supported by modern owners because of the necessity to redistribute the structure of ownership and, as a consequence, the structure of management between them. Moreover, the coming of the new owner causes organizational difficulties because of the need to re-register the enterprise. Besides, one can assert unattractive investment climate in Ukraine to predict whether foreign investors will come. Thus, we can conclude that the increase in the authorized capital is rather theoretical than practical means of increasing company's own capital.

2. Increase in the additional capital due to:

- the sale of shares issued at a price above nominal;

- additional evaluation of the company's assets;

- the value of non-current assets obtained free of charge from other persons.

Additional evaluation of assets increases only the paper value and does not increase a real financial coverage of company's assets, and because of this the additional evaluation of current assets cannot be considered as company's additional capital. As for the other two directions of the growth of the company's additional capital, it can be noted that under a limited range of financially stable and important market actors an accurate forecast of practical implementation of measures in these directions is not possible. Thus, we can conclude that the practical increase in company's own capital due to the growth of its additional capital is limited.

3. Increase in the amount of the reserve capital becomes possible in case of increasing deductions from the net profit and it can be used for the company's development, so it is a direct method of providing future capitalization of the company. Thus, there are all grounds to state that the new normative deductions from the net profit of the company should be increased in order to increase its reserve capital and expand company's own financial capabilities for providing its future capitalization.

4. Increase in undistributed profit is possible if company's dividend policy is revised, namely if the size of dividend payments is reduced, and the size of undistributed profit is increased in order to expand the 


\section{A. Y. Mohylova}

enterprise's own financial capabilities for providing the enterprise's growth strategy. However, the practical implementation of changes in the dividend policy aimed at reducing dividend payments often faces disagreement of current owners. Therefore, it can be concluded that the increase in enterprise's own capital due to the undistributed profit cannot always be realized in practice.

Having analyzed the trends of increasing the company's own capital in terms of ensuring its capitalization, one can summarize that, taking into account the organizational constraints imposed by the enterprise owners as well as economic expediency, the formation of the reserve capital and the undistributed profit in increased volumes as the result of changing the policy of distributing the company's net profit is the most probable.

Another serious problem that needs to be addressed, while ensuring the future capitalization of the company, is the identification of directions for investing capital. We believe that the increase of capital and volumes of finished products is the direction of high priority for the increase of company's assets. Under other equal conditions, the increase of basic assets of modern high technical level is the factor of production growth, which, in turn, leads to the increase in sales growth, expansion of company's market share and cyclically to the necessity of expanding the park of equipment, i.e., in this way the value of company's assets grows which gives grounds to talk about its capitalization.

To provide a real capitalization, one should pay special attention to such source of company's own financial resources as the depreciation fund. The value of depreciation charges depends on the initial value of company's basic assets, which the company is able to increase or decrease independently. The practice of selling industrial machines proves the possibility of using both variants of sale. If the company buys technological machines at a lowered price, in the future it will face the problem of the depreciation fund insufficiency that will make it impossible to carry out a full renovation of equipment. The owners of enterprises privatized in the 1990s experienced a similar scenario of their own production base development when the property was transferred to a new owner at the residual value without a cumulative depreciation fund. Thus, a low cost of production equipment eventually makes impossible to renew physically and morally outdated equipment and reduces the technological potential of the company.

In the opposite case, if the company manages to increase the value of its production equipment through its additional evaluation as a result of completion, modernization, reconstruction or technical re-equipment, it faces the problem of increased prime cost of products that were manufactured using the given equipment complex, since the increase of equipment cost increases the amount of depreciation charges. The increase of prime cost inevitably causes the increase of the selling price which under other equal conditions reduces the volume of sales and worsens the company's image. Thus, we can conclude that any changes in the value of production equipment will eventually have a negative impact on future capitalization of the company because it does not strengthen its own financial base.

External economic conditions, in which market actors operate, specify the minimum size of company's capitalization. At the same time, it can be assumed that the external environment also determines the possibility of the highest level of capitalization. This conclusion is proved by the results of the research presented in the work of the Russian scholar E.P. Tavokin that deals with the nature crisis development in the market system. Treating the crisis as a "sharp, drastic change in anything, hard transition state, or special complications, under which the inadequacy of the means of achieving goals creates unexpected problems, hidden conflicts and disparities", E. Tavokin concludes that "in any market system the internal contradictions are inevitably accumulated to the level at which this organization begins to break, i.e., a crisis comes" [12, p. 141]. Supporting this position in solving the problem of company's capitalization, we can make the following observation: the increase in company's capitalization cannot be a continuous process and has its upper limit. This is due primarily to the fact that the constant increase in the value of company's capitalization is usually accompanied by the increase in its activities, the expansion of goods presented on the market, increase of company's market share and, ultimately, increased attention to the company itself from anti-monopoly authorities, competitors who lose their market positions, and entities capable of raider attacks on perspective enterprises. Therefore, there is a relationship 


\section{Capitalization of the industrial enterprise: specifics of modern management}

between the objectively maximum value of the company's capitalization and the level of competition on the market. So, it is necessary to identify this relationship and to describe it mathematically. We believe that the higher the level of competition on the market, the lower the maximum and appropriate level of company's capitalization is according to the criterion of company's safe operation on the market.

The importance of the capitalization of companies in the real sector of the economy proves their role in the structure of the national economy, namely the companies of basic industries provide the basis for functioning and developing enterprises of infrastructural sectors, such as transport, communications, trade, banking etc., i.e., the activation of the infrastructural sector begins, first of all, in the region where the company's main activities are concentrated. Then, this effect extends to the neighboring regions and covers the level of the whole country. For this reason, it is the expanded production in the real sector of the economy that the economic growth of the whole country depends on. Moreover, the social effect is achieved, which is manifested in the growth of incomes of the population due to the growth of the employees' wages in those companies that achieved the growth of their capitalization.

It can be argued that there is a relationship and interdependence between the level of market capitalization of the real sector's companies and the efficiency of production. Thus, the market capitalization is a result of the production efficiency. At the same time, the market capitalization is the basis for the company's financial stability and determines the effectiveness of its future production activities. Expanded production stimulates the development of resource markets and activates companies' activities at the stage of distribution of manufactured products. In addition, the capitalization of companies in the real sector of the economy and the following increase of production expand the demand for the products of related industries. The increase in production leads to higher taxes which form the revenue part of the state budget. So, one can assert that in the current crisis conditions observed in Ukraine's economy the recovery and development of companies of the real sector is of high priority.

To ensure the capitalization of companies of the real sector, the attention should be paid not only to increasing the number of production factors of companies but to their quality and improvement of manufacturing processes at all stages of the production cycle. Therefore, we believe that the management of a company should be aimed, first of all, at:

- increasing the productive capital as the foundation for future growth of the company;

- promoting the sale of finished products to ensure the growth of sales revenue and profits;

- improving management of company's net profit division for the purpose of forming financial resources to increase the future growth;

- obligatory introducing innovation to create high-quality basis for the growth of company's capitalization.

Conclusions. Taking into account limited financial resources to ensure the capitalization of companies in the real sector of Ukraine's economy, we arrive at the conclusion that to recover Ukraine's economy under strengthened crisis in the economic and political spheres of society, the problem of providing a real capitalization of industrial companies is of high priority. So, the practical recommendations on improving the composition and structure of companies' productive capital mainly due to their internal capabilities are rather urgent today.

\section{References}

1. Ansoff H. I. Corporate strategy: An analytical approach to business policy for growth and expansion / H. I. Ansoff. - New York : McGrawHill, 1965. - 241 p.

2. Barney Jay B. Firm resources and sustained competitive advantage / Jay B. Barney // Journal of management. - 1991. - Vol. 17, № 1. - P. 99-120.

3. Boynlon A. C. An Assessment of Critical Success Factors / A. C. Boynlon, R. W. Zmud. // Sloan Management Review. - 1984. - Vol. 25, № 3. - P. 17-27.

4. Charreaux G. Corporate Governance: Stakeholder Value versus Shareholder Value / G. Charreaux, P. Desbrieres // Finance Controle Strategie. - 1996. № l. - P. 17-46.

5. Esteves de Sousa J. M. Definition and Analysis of Critical Success Factors for ERP Implementation Projects [Electronic resource] / J. M. Esteves de Sousa. - Access mode: http://jesteves.com/Tesis_ phd_jesteves.pdf. 


\section{A. Y. Mohylova}

6. Kehinde J. S. Effective Working Capital Management in Small and Medium Scale Enterprises (SMEs) [Electronic resource] / J. S. Kehinde // International Journal of Business and Management. 2011. - Vol. 6, № 9. - P. 271-279. - Access mode: http://www.ccsenet.org/ijbm.

7. Khrawish H. A. The Determinants of the Capital Structure: Evidence from Jordanian Industrial Companies [Electronic resource] / H. A. Khrawish, A. H. A. Khraiwesh // JKAU: Econ. \& Adm. - 2010. Vol. 24, № 1. - P. 173-196. - Access mode: http://www. kau.edu.sa/Files/320/Researches/55328_25671.pdf.

8. Mahoney J.T. The resource-based view within the conversation of strategic management/J. T. Mahoney, J. R. Pandian // Strategic Management Journal. 1992. - Vol. 13. - P. 363-380.

9. Bogutska O. A. Zabezpechennia kapitalizatsii pidpriemstv iz vykorystanniam koshtiv finansovykh institutiv / O. A. Bogutska // Problemy ta perspektyvy rozvytku ekonomiki i pidpriemnitstva ta kompiuternykh technologii $v$ Ukraini: zbirnyk tez [za materialami VIII nauk.-techn. konf. nauk.pedagogichnykh pratsivnykiv, 26-31 berez. 2012 r.] / Nats. Un-t "Lvivska politechnika", In-t pidpryemnytstva ta perspektyvnykh tekhnologii. - Lviv, 2012. - P. 180-182.

10. Moliaka O. I. Ekonometrychni modeli dlia vvedennia $v$ diiu osnovnykh fondiv / O. I. Moliaka // Formuvannia rynkovykh vidnosin $v$ Ukraini. 2003. - № 6 (25). - P. 7-9.

11. Spasiv N. Y. Ekonomiko-matematychne modeliuvannia optymalnykh obsiagiv vidtvorennia osnovnogo kapitalu pidpriemstv meblevoi galuzi / N. Y. Spasiv // Formuvannia rynkovykh vidnosyn $v$ Ukraini. 2011. - № 11 (114). - P. 161-166.

12. Tavokin E. P. Antikrizisnoe upravlenie. Chto eto takoe? / E. P. Tavokin // Vestnik Rossijskoj Akademii Nauk. - 2010 - T. 80, № 2. - S. 141-146. 